\title{
Evaluation of Physical and Chemical Parameters According to Energetic Willow (Salix viminalis L.) Cultivation
}

\author{
Kamil Roman ${ }^{1}$, Michał Roman ${ }^{2, *}$, Dominika Szadkowska ${ }^{1}$, Jan Szadkowski ${ }^{1}$ \\ and Emilia Grzegorzewska ${ }^{1}$ \\ 1 Institute of Wood Sciences and Furniture, Warsaw University of Life Sciences in Warsaw, \\ Nowoursynowska 166 Street, 02-787 Warsaw, Poland; kamil_roman@sggw.edu.pl (K.R.); \\ dominika_szadkowska@sggw.edu.pl (D.S.); jan_szadkowski@sggw.edu.pl (J.S.); \\ emilia_grzegorzewska@sggw.edu.pl (E.G.) \\ 2 Institute of Economics and Finance, Warsaw University of Life Sciences in Warsaw, \\ Nowoursynowska 166 Street, 02-787 Warsaw, Poland \\ * Correspondence: michal_roman@sggw.edu.pl
}

Citation: Roman, K.; Roman, M.; Szadkowska, D.; Szadkowski, J.; Grzegorzewska, E. Evaluation of Physical and Chemical Parameters According to Energetic Willow (Salix viminalis L.) Cultivation. Energies 2021, 14, 2968. https://doi.org/ 10.3390/en14102968

Academic Editor: Brian D. Fath

Received: 16 March 2021

Accepted: 18 May 2021

Published: 20 May 2021

Publisher's Note: MDPI stays neutral with regard to jurisdictional claims in published maps and institutional affiliations.

Copyright: (C) 2021 by the authors Licensee MDPI, Basel, Switzerland. This article is an open access article distributed under the terms and conditions of the Creative Commons Attribution (CC BY) license (https:// creativecommons.org/licenses/by/ $4.0 /)$.

\begin{abstract}
The aim of this study was the investigation of the effect of growth conditions of energy willow (Salix viminalis L.) on its physical and chemical parameters towards lignocellulosic biofuels. This work is linked to the global trend of replacing fossil fuels (coal, oil, natural gas) with energy and renewable fuels. This energy transition is dictated by the reduction of the human-induced greenhouse effect (to the greatest extent by industrial development). Changing from traditional to renewable energy sources results in industry becoming less dependent on fuels whose sources are beginning to run out, and in energy processing being broken down into smaller sectors with greater flexibility to change and less susceptibility to failure. The use of lignocellulosic raw materials such as wood, straw, food industry waste, wood, and post-consumer products such as old furniture for energy purposes allows the use of substances which bind the greenhouse gas carbon dioxide in their cellular structure during growth. In order to optimise the costs of producing such energy and minimise its impact on the environment, these plants should be located as close as possible to the source of raw materials. One of the most important characteristics for the profitability of energy production from woody biomass is a high biomass yield. For this purpose, the raw material used for this study was energy willow (Salix viminalis L.) seedlings, which are often used for energy crops. Due to the moisture-loving nature of the substrate, the effect of the addition of the active substance prednisonum as a catalyst for water adsorption from the substrate was investigated. In order to determine the substances formed during the thermal decomposition of energy willow (Salix viminalis L.) wood, a pyrolysis process was carried out at $450{ }^{\circ} \mathrm{C}$ using pyrolysis gas chromatography mass spectrometry (PY/GC-MS).
\end{abstract}

Keywords: PY/GC-MS; prednisonum; energetic willow; water adaptation; agricultural farm; growth

\section{Introduction}

The growing interest of renewable resource participation in energy production was caused by the increase in widespread energy consumption. Renewable energy is one of the alternatives for fossil fuel limitation and climate change and helps to increase energy security. Fossil fuels have a large share in the energy sector and can be the cause of huge emissions of greenhouse gases (GHGs). Especially in the industrial era, the increasing concentration of various greenhouse gases in the atmosphere is the dominant factor for climate change. That is why in 2007, the Member States accepted the so-called climate and energy package, the assumptions of which are, e.g., limiting the GHG emissions and enhancing energy security. One of the ways to accomplish those objectives is to increase the share of energy from renewable resources in total consumption. Special attention must be given to solid biomass, e.g., energetic willow. That renewable energy is considered to show 
potential as it is a stable and predictable source meeting a number of positive functions not only for the electrical power system, in addition to the energy and economic benefits as well as the environmental ones; it decreases the GHG emissions and provides global and local social benefits. It helps activate the rural areas, it creates new jobs, and it enhances the investment attractiveness of a region [1].

Social consciousness changes in the 20th century brought about a forced change in the energy policies presented by the global economy. These factors were compounded by the spread and confirmation of knowledge regarding the impact of industry (especially energy) on the greenhouse effect and fuel crises [2]. These changes led to the development of what is known as the sustainable economy. Initially, greenhouse gas emissions from product manufacturing were to be offset by the use of renewable energy. It was then decided to take into account all the greenhouse gases produced by the industry by introducing the concept of a carbon footprint, which corresponds to the amount of greenhouse gases required to produce and utilize a product in terms of carbon dioxide [3]. One way to reduce the carbon footprint is to use regionally produced lignocellulosic biomass in power generation. Energy from this type of raw material also makes it possible to make the regional economy less dependent on raw material supply problems from other parts of the world [4]. The biomass used should be characterized by a relatively high yield and should be a resource not only for the energy industry, which affects the profitability of its production and its stability [5]. An important social aspect is the use for energy purposes of lignocellulosic biomass, which is not a product used in the food industry [6].

The current interest and development of research in the field of renewable energy allows for a deeper look and a more accurate comparison of ecological solutions [7]. For example, Directive 28/2009/EC has been developed as a priority strategy for climate protection and sustainable energy policy. The measures include an intensification of the work of European Community member states in the field of energy saving and efficiency and the need to look for ecological alternatives. Figure 1 and Table 1 present the share of energy from renewable sources in total primary energy in the years 2009-2019.

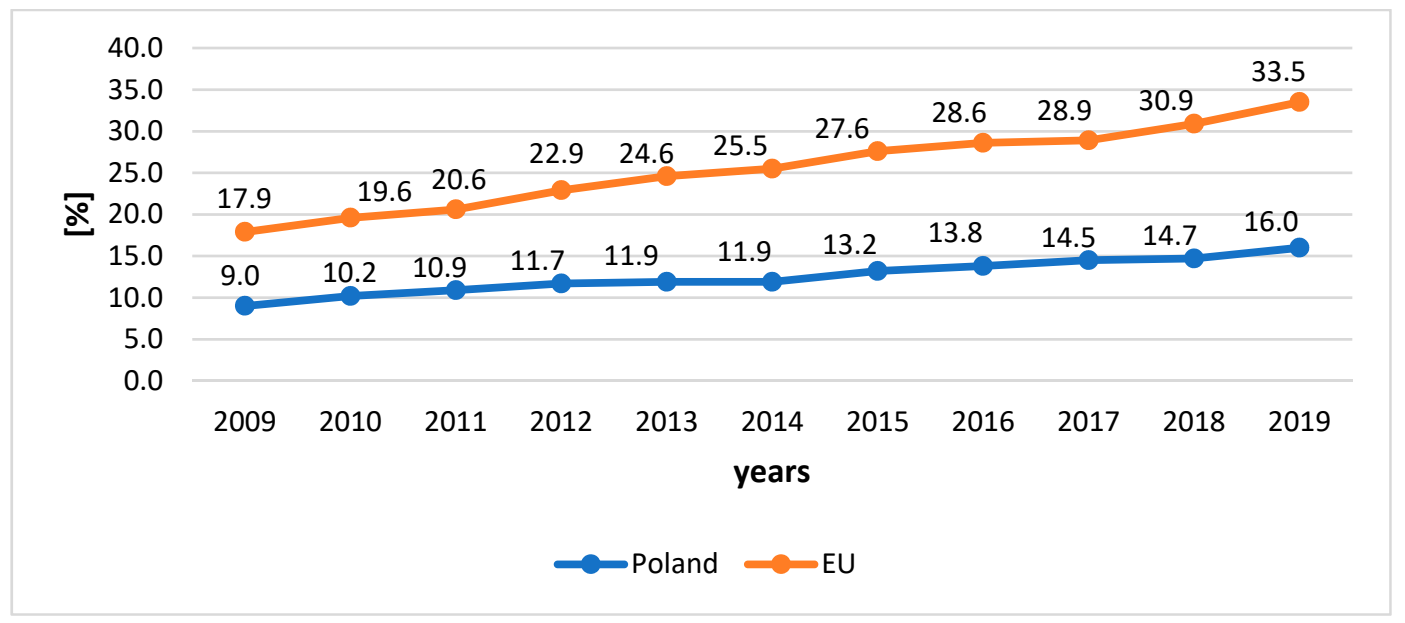

Figure 1. Share of energy from renewable sources in total primary energy in the years 2009-2019 [\%]. Source: [8-10]. 
Table 1. The share of renewable energy commodities in the total renewable energy in Poland in the years 2009-2019.

\begin{tabular}{ccccccccccccc}
\hline Specification & $\mathbf{2 0 0 9}$ & $\mathbf{2 0 1 0}$ & $\mathbf{2 0 1 1}$ & $\mathbf{2 0 1 2}$ & $\mathbf{2 0 1 3}$ & $\mathbf{2 0 1 4}$ & $\mathbf{2 0 1 5}$ & $\mathbf{2 0 1 6}$ & $\mathbf{2 0 1 7}$ & $\mathbf{2 0 1 8}$ & $\mathbf{2 0 1 9}$ \\
\hline Solid biofuels & 85.77 & 85.29 & 85.00 & 82.07 & 79.88 & 76.14 & 73.54 & 69.98 & 66.94 & 68.08 & 65.56 \\
Solar energy & 0.11 & 0.12 & 0.14 & 0.17 & 0.29 & 0.43 & 0.56 & 0.69 & 0.74 & 0.92 & 1.40 \\
Hydro & 3.37 & 3.65 & 2.68 & 2.06 & 2.45 & 2.31 & 1.76 & 2.01 & 2.37 & 1.88 & 1.78 \\
Wind & 1.53 & 2.08 & 3.69 & 4.79 & 6.03 & 8.13 & 10.41 & 11.81 & 13.82 & 12.19 & 13.72 \\
Biogas & 1.62 & 1.67 & 1.83 & 1.97 & 2.12 & 2.56 & 2.55 & 2.85 & 3.02 & 3.19 & 3.15 \\
Liquid biofuels & 7.04 & 6.64 & 5.76 & 7.96 & 8.18 & 9.18 & 9.02 & 10.06 & 9.89 & 10.03 & 10.36 \\
Geothermal energy & 0.24 & 0.20 & 0.17 & 0.19 & 0.22 & 0.25 & 0.24 & 0.24 & 0.24 & 0.26 & 0.26 \\
Minicipal waste & 0.01 & 0.04 & 0.43 & 0.38 & 0.39 & 0.45 & 0.45 & 0.45 & 0.67 & 1.09 & 1.08 \\
Heat pumps & 0.30 & 0.31 & 0.30 & 0.41 & 0.44 & 0.55 & 1.48 & 1.48 & 1.71 & 2.37 & 2.69 \\
\hline & & \multicolumn{7}{c}{ Source: $[8-10]}$. & & & &
\end{tabular}

In 2009-2019, the share of energy from renewable sources in total primary energy increased in Poland by 7 pp. from 9.0 to $16.0 \%$ (Figure 1). It should be emphasized that at the same time, on average in the EU countries, this indicator increased from $17.9 \%$ to $33.5 \%$. Under domestic conditions, energy from renewable sources includes energy from solar radiation, water, wind, geothermal resources, energy generated from solid biofuels, biogas and liquid biofuels, as well as ambient energy obtained by heat pumps. The structure of obtaining energy from renewable sources in Poland differs from the structure of obtaining energy from renewable sources in the EU-28 countries. This is mainly due to the geographic conditions characteristic of Poland and the resources that can be managed.

Solid biofuels play a dominant role in obtaining domestic energy from renewable sources. Although their share in obtaining energy from renewable sources in 2009-2019 decreased from 85.77 to $65.56 \%$ (Table 1), solid biofuels are still the most important. In the period under discussion (2009-2019), the share of wind energy increased from $1.53 \%$ to $13.72 \%$, liquid biofuels from $7.04 \%$ to $10.36 \%$, and biogas from $1.62 \%$ to $3.15 \%$. In 2019 , heat pumps ranked relatively high in obtaining energy from renewable sources by carriers (from 0.30 to $2.69 \%$ ), ahead of water, solar, municipal waste, and geothermal energy.

The most interesting lignocellulosic biofuels classified as solid biofuels are straw, wood, including wood from plantations intended for energy purposes, forestry waste, and waste from the paper and wood industry [11]. They can be used as biomass for the production of more advanced fuels and substances or burned directly in adapted equipment [12].

Eco energy is also about energetic removable resources. In the case of bioenergy, raw materials are crops that grow for energy purposes. The most important features of that fuel are the feedstock of high biomass yield and the most favorable calorific parameters. The highest energy efficiency and a relatively high yield of biomass have been found for willow energetic willow (Salix viminalis L.), Poplar (Populus L.), giant miscanthus (Miscanthus sinensis giganteus), and Sida hermaphrodita rusby or some grasses, e.g., reed brain (Phalaris arundinacea). The average period of operation of energy plantations is 15-20 years [13].

In Poland, the development of the biomass market takes place in a chaotic manner, mainly through entrepreneurship of small companies and farmers. Besides the guidelines imposed by energy producers, there are practically no regulations in this field. The issues of the development of renewable energy depends on the ministry of agriculture, environmental protection, and economy. The effects of activities that can be seen today clearly show that these are not correlated activities, e.g., willow cultivation is treated as a forest crop and is excluded from grants. The consequence creates the fact, that if there is no strategy, there is no specific funding source.

The development of the biomass market will have a future if a clear vision of its use in line with the country's development is created from the very beginning. The profitability of energy crops also depends on the economic situation and the activities of energy companies. Recent years have confirmed the declining interest in this type of biomass from Polish growers in favor of cheaper imported biofuels. The above-mentioned measures result from the reduction of co-firing and suspension of special subsidies. As a consequence, it 
causes the elimination of small energy crops. Their biomass can be replaced with available and relatively cheap forest biomass. Some literature sources provide information on the increase in the production of perennial energy crops (2010 -6193 ha, 2011 — 7619 ha, 201210,344 ha, 2013 - 11,509 ha) [13], which may be caused by the establishment of large, private plantations by producers of heat and electricity.

One of the tree species used to create plantations for energy purposes in Europe is energy willow (Salix viminalis L.). This species has fast-growing varieties. Additionally, it is frost hardy and has non-sensitive varieties. Its advantage is the possibility of growing on soils, light (sandy), medium (loamy), and heavy (clay) soils, and can grow in heavy clay soil. It is also insensitive to the $\mathrm{pH}$ of the soil in which it grows. The disadvantage is the plant's demand for water (it needs moist or waterlogged soils) [14]. Plant raw materials such as energy willow (Salix viminalis L.) can also be used for direct combustion. By cutting its structure across the fibres, a form of the raw material is created, referred to as "long strands" or "short strands". Thus, the prepared material is physically similar to pellets or briquettes. Presumably, improvement of physical parameters of the raw material may require chemical interference.

It was assumed that increasing water uptake would allow the plant to accelerate photosynthesis, leading to swelling of the material tissue. Increasing water uptake requires the use of a catalyst (active substance); in this case, prednisonum was used.

Prednisonum is an active substance belonging to the glucocorticoid steroid group and an analogous form of cortisol [15]. In medicine, is used as a powerful anti-inflammatory, -allergic, and -rheumatic medical substance. The activity of prednisonum is manifested by the water accumulation in the cellular structure [16], the action of which was used as a paradigm in further empirical analysis.

The choice of analyzed material was not accidental. The energetic willow is a plant with C4 photosynthesis $[17,18]$, characterized by a large mass increase in a short period of time [19]. Energetic willow has the potential and the possibility of additional management $[20,21]$. The energetic willow (Salix viminalis L.) is a plant that can be grown on farms for energetic use [22]. It is planted for biomass purposes, which can be obtained from the grown plants [23]. The cultivation of energy crops perfectly fits into the concept of sustainable development of agriculture and rural areas, which aims at achieving economic goals, as well as meeting environmental requirements and social expectations [24]. Therefore, renewable fuel should not contain contaminants such as heavy metals or other contaminants. The best and most common analysis characterizing the purity of fuel is the chemical analysis of the composition of the raw material.

Energetic willow growth is related to hygroscopicity $[25,26]$, which was used to transport prednisonum. Water is an essential ingredient in the energetic willow cultivation as a means of biomass production [27-29]. The energetic willow is characterized by high transpiration, which forces the water demand during the vegetation period [30,31]. The water demand in the vegetation period according to various sources is in the range of 100-1790 mm, depending on the place of cultivation and the method of fertilization. The aim of laboratory studies was to analyze energetic willow (Salix viminalis L.) grown under laboratory conditions. The study also included the analysis of compounds released to the atmosphere at a temperature of $450{ }^{\circ} \mathrm{C}$, which corresponded to the temperature of the burned raw material [31] using the method of chemical analysis, PY/GC-MS. The performed studies allowed us to determine the physicochemical properties of the raw material grown in vases.

\section{Materials and Methods}

\subsection{Energetic Willow Vase Tests (Salix viminalis L.)}

Energetic willow cultivation, to be more valuable, requires sufficient water. The crop should be watered heavily in the first year of cultivation, before the root system is formed. In the following years, the cultivation of energy willow is less labor-intensive. However, you still need to provide the right amount of water and even ensure proper fertilization of 
the plantation. With two- or three-cm-thick cultivated shoots, energy willow can be cut. The entire cultivation of the energy willow is not complicated. Each plantation requires proper care and the provision of water and nutrients for a given crop.

The molecular action of prednisonum led the authors of the article to carry out research on the adaptation of water in the cultivation of energetic willow in the vase test. The share of prednisonum in a uniform growing environment for both plantations will allow us to specify the properties of substances of a given plant species. The established energetic willow research plantation was prepared in two stages. In the first stage, the energetic willow in the form of cuttings was kept for three weeks in a container with water until the shoots and root system developed. Pictures showing the growth of shoots and the root system are presented in Figure 2.

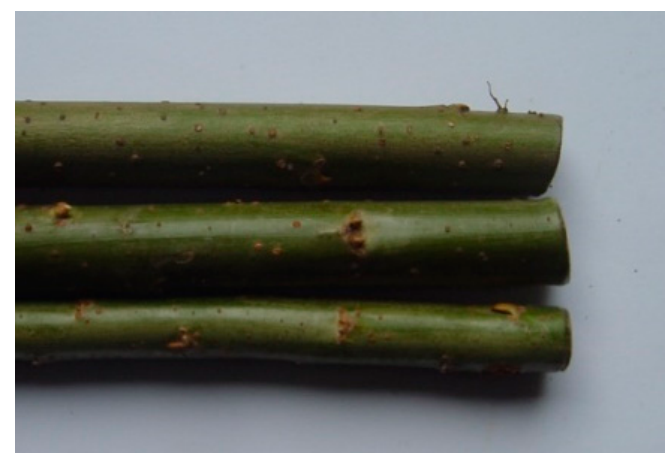

(a)

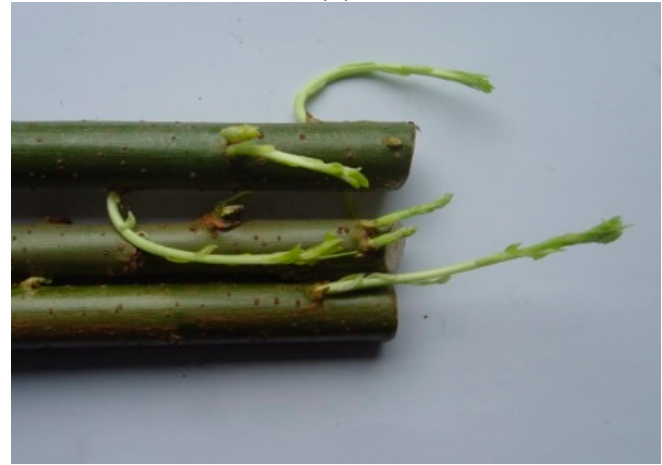

(c)

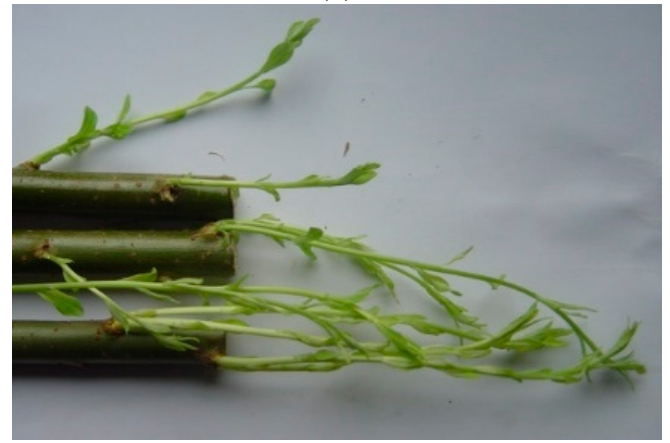

(e)

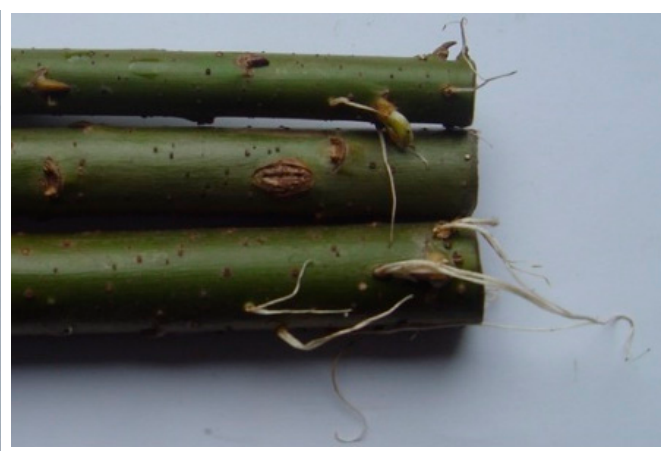

(b)

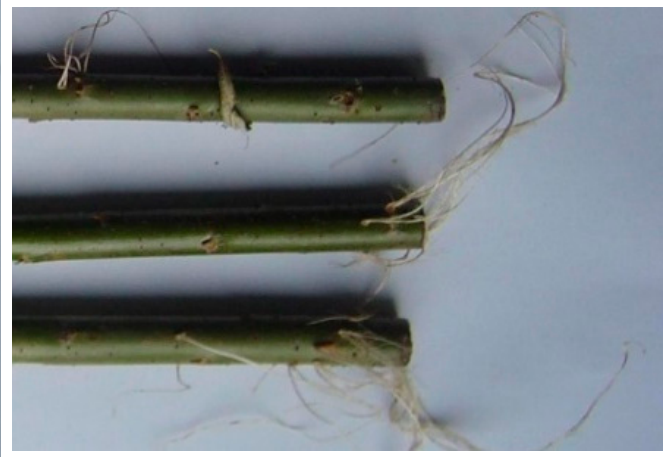

(d)

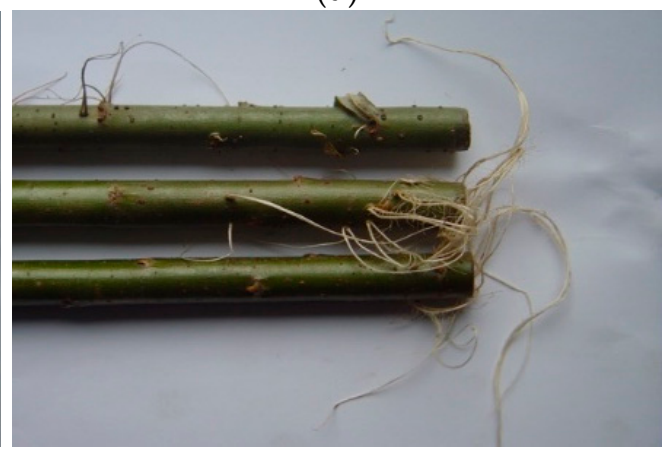

(f)

Figure 2. Cultivation: shoots: (a) 1 week, (c) 2 weeks, (e) 3 weeks; Root system: (b) 1 week, (d) 2 weeks, (f) 3 weeks.

The experiment was carried out under laboratory conditions, where the ambient temperature was around $22^{\circ} \mathrm{C}$. Young seedlings were placed in two identical pots with a diameter of $50 \mathrm{~cm}$ to reduce the loss of water from prednisonum to the soil. Five energetic willow plants were placed in both pots. The research plantation was maintained for a period of four months. During the cultivation period, prednisonum was added to the first 
crop, where the applied dose was $20 \mathrm{~g}$ and was introduced with water into the soil every third day. Clean water was added to the soil of the second pot at identical intervals. Every three days, plants were watered, with and without prednisonum. Prepared pots with an energetic willow after four months of cultivation are presented in Figure 3.

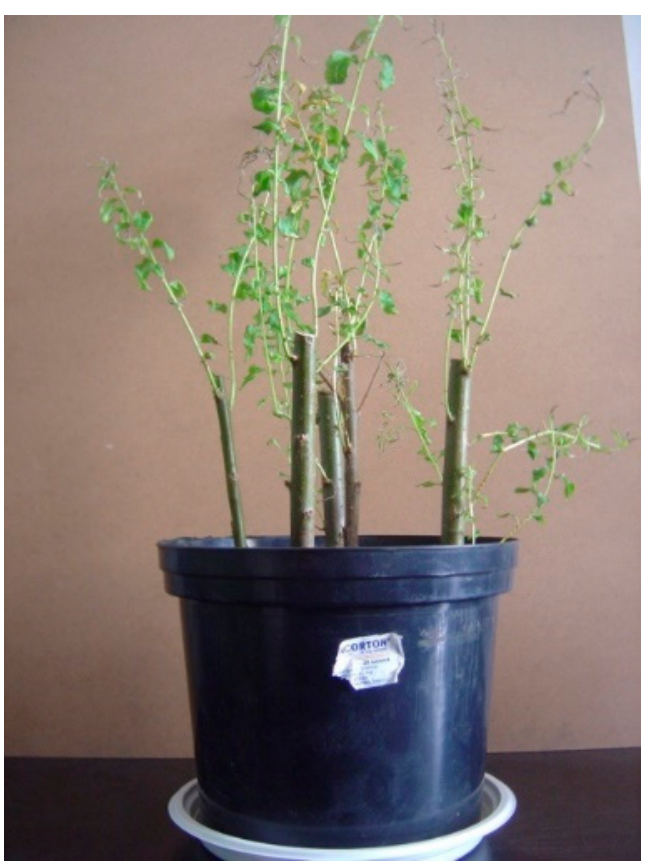

(a)

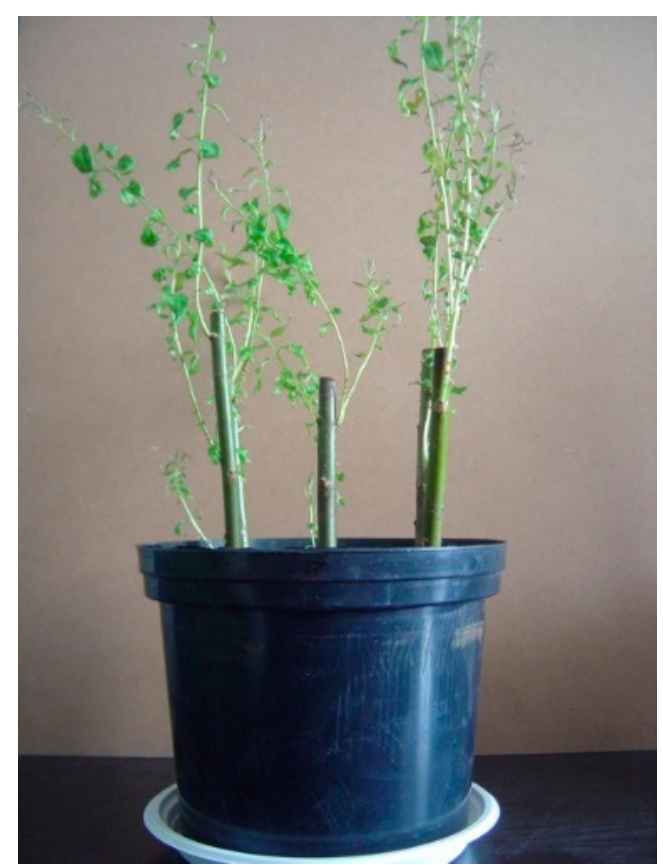

(b)

Figure 3. Cultivation of energetic willow: (a) fertilized with prednisonum, (b) without prednisonum.

After the energetic willow plantation was exterminated, the physical properties of the energetic willow and the soil were determined. Raw material and soil samples were taken from both crops to estimate the effect of prednisonum on the moisture content.

The results of the study were analyzed statistically, determining the impact of parameters of the measured raw material on the water adaptation in the process of growing energetic willow. During the statistical analyses, ANOVA was used. The statistical analysis determined the influence of common factors empirically determined as moisture values depending on the proportion of prednisonum in the soil. The method combined in special cases with a post-hoc test allowed us to determine the belonging of the measured parameters to a given homogeneous group.

\subsection{Measurements of Pyrolysis Gas Chromatography Mass Spectrometry (PY/GC-MS)}

Pyrolysis gas chromatography mass spectrometry (PY/GC-MS) is a method of chemical analysis. The analysis of components was performed using a Shimadzu gas chromatograph GC-2010 (Kyoto, Japan) connected to the pyrolizer Fronteir linked to a GCMS-QP2010 mass spectrometer. An Ultra-Alloy capillary column with a length of $30 \mathrm{~m}$, a diameter of $0.25 \mathrm{~mm}$, and a deposit of $0.25 \mu \mathrm{m}$ was used. During analysis, the sample is heated until the decomposition material produces smaller molecules that are separated through the gas chromatograph and detected by mass spectrometry [31]. The samples were analyzed using a dedicated program-GCMSsolution Version 2.72. The peaks were identified with NIST11 and NIST11b libraries. The identified relationships in the database had a minimum of $70 \%$ correlation to libraries.

The pyrolysis analysis-gas chromatography-mass spectrometry (PY/GC-MS) program consisted of a GC-MS module (gas chromatograph oven with injector and chromatography column and mass detector) in which the following program was set: initial temperature, $85^{\circ} \mathrm{C}$, held for $0.5 \mathrm{~min}$, raised to $145^{\circ} \mathrm{C}$ at $15^{\circ} \mathrm{C} / \mathrm{min}$, held for $15 \mathrm{~min}$, then raised to 
$200{ }^{\circ} \mathrm{C}$ at a rate of $10{ }^{\circ} \mathrm{C} / \mathrm{min}$ and held for $15 \mathrm{~min}$, and a pyrolysis module (PY) in which the process temperature was set to $450^{\circ} \mathrm{C}$ with a holding time of $25 \mathrm{~min}$. Approximately $2 \mathrm{mg}$ of willow vase test chips (Salix viminalis L. in an absolutely dry condition (the thermal decomposition process was performed six times) was used for a single analysis. The gas flow rate was $0.97 \mathrm{~mL} / \mathrm{min}$, and the detector voltage was $0.9 \mathrm{kV}$. The carrier gas was helium-(PGNiG, Warszawa, Poland). During PY/GC-MS measurements, the temperature and time of the wood combustion process were taken into account in order to determine the components formed by pyrolysis of the analyzed material.

\subsection{Statistical Analysis}

The parameter values for further statistical analysis were collected in three replications. Statistical analysis consisted of examining the variance with multiple classification, which allowed us to determine the impact of the analyzed parameters on the population of the selected combination of factors. In order to confirm these regularities, Duncan's test was carried out by analyzing statistical statements. The performed test compared the control variables of the assumed parameters, classifying the factors into individual homogeneous groups. If there was no relationship, only charts illustrating a given character were presented as a result.

Analytical tools in the form of multivariate ANOVA with the use of the Statistica computer program were used for the statistical analysis of the laboratory test results. The method allowed us to determine the influence of arguments, or function parameters (physicochemical properties), on cultivation parameters, assuming that other factors were unchanged, i.e., ceteris paribus.

The method allows us to identify a group of factors that have a statistically significant influence on the parameters tested. In the study, the specified groups of factors were compared with the assumed classification criteria. During the analysis, the value of $\alpha$ was taken into account, characterizing the level of significance, expressing the probability of a mistake in the selection of the confidence coefficient. In the statistical analysis, taking into account the verified residual hypotheses, the value of $\alpha$ was assumed to be 0.05 , which is the difference between unity and the confidence coefficient $\mathrm{F}$ of 0.95 , i.e., $\mathrm{F}=1-\alpha$. The determination of the resulting intergroup error consisted of determining the ratio of the sum of the intergroup squares to the number of degrees of freedom. The results of the statistical analysis were also influenced by the nature of the problem and the accuracy of the distribution of means.

\section{Research Results and Discussion}

Physical analysis is the division of the entire component into individual elements to determine the characteristics of the subject [32]. The cognitive objective of the research was to determine the physical properties of energetic willow cuttings, which during the cultivation were subjected to the action of active substances in the form of prednisonum compounds. Energetic willow plantlets placed in a pot with soil at a distance of about $10 \mathrm{~cm}$ are presented in Figure 4.

The research has allowed us to develop, to date, limited knowledge of water adaptation features using a catalyst in the form of an active substance called prednisonum. The analysis of cultivation consisted of determining the physical properties of the raw material, taking into account the length of shoots of the plant and the degree of its moisture. The increase in material mass was determined by measuring the length of energetic willow shoots after four months of cultivation. The measurement accuracy was $0.5 \mathrm{~mm}$. The results are presented in Table 2. 


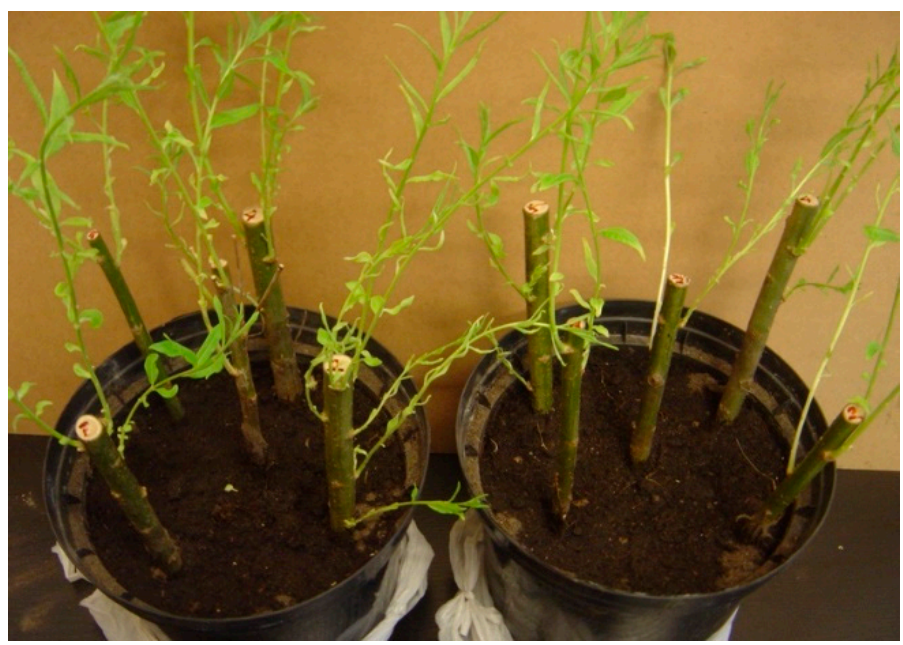

Figure 4. Spacing of energetic willow during the cultivation.

Table 2. Growth of energetic willow shoots after four months of cultivation.

\begin{tabular}{|c|c|c|c|c|c|c|c|c|c|c|}
\hline \multirow{2}{*}{ Shoots } & \multicolumn{5}{|c|}{ Fertilized with Prednisonum } & \multicolumn{5}{|c|}{ Without Prednisonum } \\
\hline & 1 & 2 & 3 & 4 & 5 & 1 & 2 & 3 & 4 & 5 \\
\hline \multirow{7}{*}{ Shoots length, $\mathrm{mm}$} & 23.5 & 11 & 20.5 & 15.0 & 17.0 & 26.5 & 24.0 & 19.0 & 7.5 & 8.0 \\
\hline & 25.0 & 13.5 & 6.0 & 35.5 & 22.0 & 20.0 & 24.5 & 14.5 & 27.0 & 16.0 \\
\hline & 3.5 & 25.0 & 24.0 & 25.0 & & & 23.0 & 14.5 & 20.0 & 4.5 \\
\hline & & 22.5 & & 14.0 & & & & 10.0 & 22.0 & 16.0 \\
\hline & & 11.0 & & 14.0 & & & & & 5.0 & \\
\hline & & 21.0 & & & & & & & & \\
\hline & & 10.0 & & & & & & & & \\
\hline Totality & & & 20 & & & & & 18 & & \\
\hline
\end{tabular}

The results of the measurements were statistically analysed using one-way analysis of variance. The statistical analyses allowed us to characterize the effect of prednisonum fertilization on the length of energy willow sprouts. The significance value was $p=0.9976$, where the empirical value of statistic $F=0.0061$. In connection with the above, the statistical analysis showed no significant differences between the measured parameters. The significance of the effect of prednisonum fertilization on the length of energy willow shoots is shown in Figure 5.

Statistical analysis consisted of estimating parameters of the random variable distribution on the basis of interval estimation (assigning numerical values for a certain interval with a certain estimated probability) [33,34]. The numerical range estimated with the assumed probability as the confidence interval contained an unknown, real value of the parameter belonging to the general population. The chart shows the confidence intervals that can be read as vertical bars with a range of 0.95 . Confidence intervals have been defined as an arithmetic mean.

The probability determining the actual location of specific parameters is expressed by the confidence coefficient $(1-\alpha)$ (percentage confidence interval $100(1-\alpha)$ ). In the next stage of the conducted experiments, the moisture content of the prepared energy willow elements cultivated as part of the subject studies was determined. Samples for testing in the form of stoppers were prepared by cutting them from the cut in the form of small elements. The physical characteristics of prepared energy willow samples are presented in Table 3. 


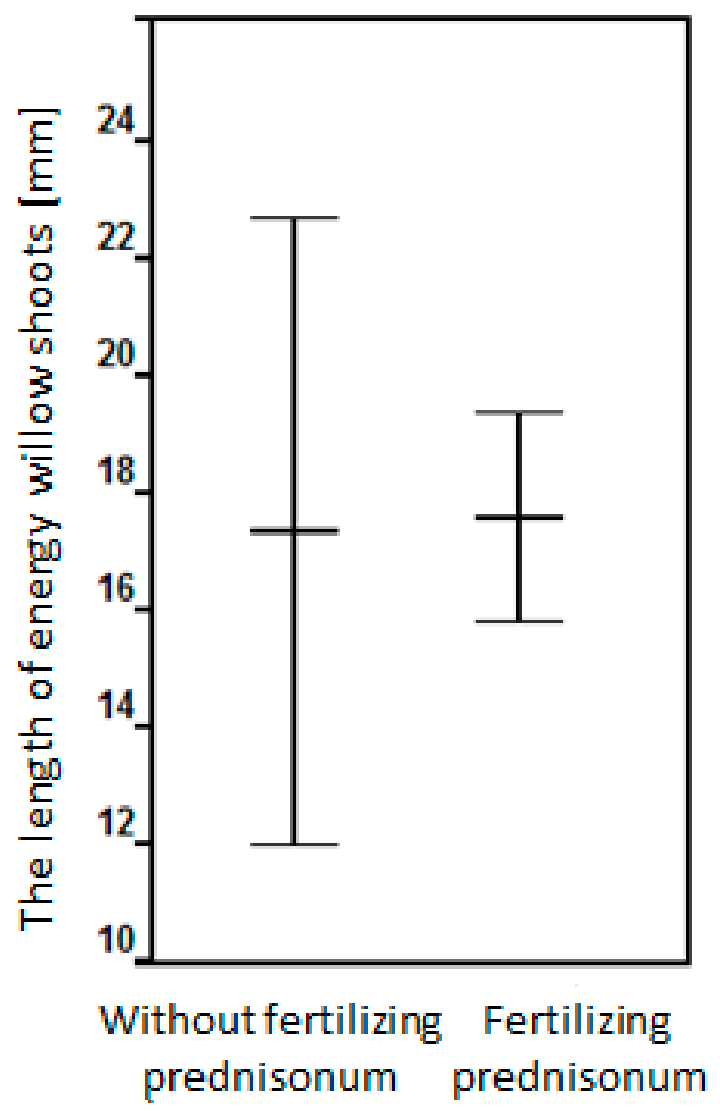

Figure 5. Significance of the effect of prednisonum fertilization on the length of energy willow shoots. Source: Own study.

Table 3. Physical characteristics of prepared samples.

\begin{tabular}{ccccc}
\hline \multirow{2}{*}{ Sample Number } & \multicolumn{2}{c}{ Shoots Fertilized with Prednisonum } & \multicolumn{2}{c}{ Shoots without Prednisonum } \\
\cline { 2 - 5 } & $\begin{array}{c}\text { Diameter of the } \\
\text { Sample, } \mathbf{~ m m}\end{array}$ & $\begin{array}{c}\text { Length of the Sample, } \\
\mathbf{m m}\end{array}$ & $\begin{array}{c}\text { Diameter of the } \\
\text { Sample, } \mathbf{m m}\end{array}$ & $\begin{array}{c}\text { Length of the Sample, } \\
\mathbf{m m}\end{array}$ \\
\hline 1. & 11.5 & 18.4 & 8.3 & 10.6 \\
2. & 12.0 & 19.7 & 8.3 & 18.2 \\
3. & 11.8 & 32.0 & 8.9 & 23.1 \\
\hline
\end{tabular}

The moisture measurement was made according to the methodology. A defined curve of energy willow drying fertilized with prednisonum and without prednisonum is presented in Figure 6.

The results of energy willow moisture measurements were subjected to statistical analysis defining the relationships between the measured parameter and the type of fertilization. During the analysis, no significant differences were observed. The significance value was $p=0.4206$, where the value of $F=3.11250$. The degree of significance was lower than the level of significance, which was set at $0.05(5 \%)$. The existing dependencies are presented in Figure 6. 


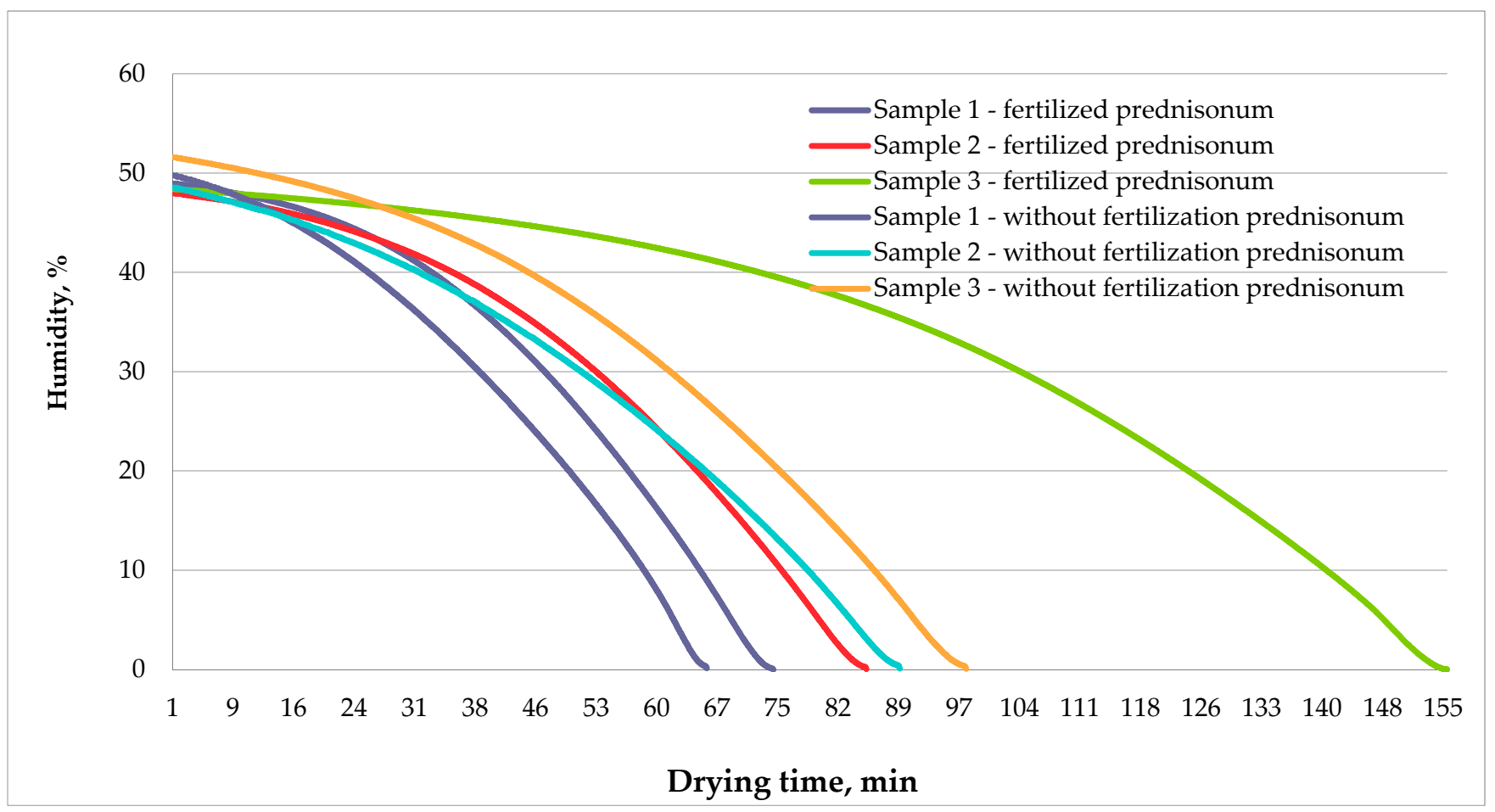

Figure 6. Drying curve for energy willow samples.

In the course of the research, the soil moisture in which the energy willow was grown was determined. The physical characteristics of prepared samples was presented in Table 4 .

Table 4. Physical characteristics of prepared samples.

\begin{tabular}{ccc}
\hline Sample Number & $\begin{array}{c}\text { Mass of Soil Fertilized with } \\
\text { Prednisonum, }\end{array}$ & $\begin{array}{c}\text { Mass of Soil without } \\
\text { Prednisonum, }\end{array}$ \\
\hline 1 & 5123 & 5112 \\
2 & 5013 & 5115 \\
3 & 5006 & 5005 \\
\hline
\end{tabular}

The defined soil drying curve under which the energy willow was cultivated without prednisonum and fertilization with prednisonum is presented in Figure 7. In the light of statistical analyses, it was found that the soil moisture under which the energy willow was grown did not show significant differences in the case of fertilization with prednisonum and in its absence. This was confirmed by the significance value $p=0.7018$ and the empirical value of $\mathrm{F}=1.0652$. The existing dependencies are presented in Figure 8 .

On the basis of the conducted research, it was noted that statistical analysis concluded that there were no significant differences between biomass from energy willow cultivated naturally and not fertilized with active substances. The soil moisture content did not differ between the analyzed crops. The average time of drying the energetic willow with a moisture of about $49 \%$ was on average $100 \mathrm{~min}$, and for the soil with a moisture content of about $38 \%$ was on average $28 \mathrm{~min}$.

Because statistical analyses showed no significant differences (as observed in Figure 8), it was decided to analyze the raw material using the PY/GC-MS chemical method. Analysis of the sample consisted of qualitative determination of the substance using pyrolysis. The research was conducted using a sample of raw material, which was not cultivated with prednisonum. The choice of this type of raw material for further studies was due to the result of the first stage of research, saying that there is no need to use this type of active agent during cultivation of energy willow. PY/GC-MS examination allowed 
characterization of the substances formed, which accompanied the combustion of the raw material. The study of energy willow was conducted at $450{ }^{\circ} \mathrm{C}$. The choice of temperature was not accidental, because it was assumed that the temperature at which the tests were conducted corresponded to the temperature of the raw material burned in a standard furnace used in heating. The amount of emissions of isolated substances after pyrolysis at $450{ }^{\circ} \mathrm{C}$ is presented in Figure 9. Juxtaposition of emissions of isolated substances at $450{ }^{\circ} \mathrm{C}$ is summarized in Table 5.

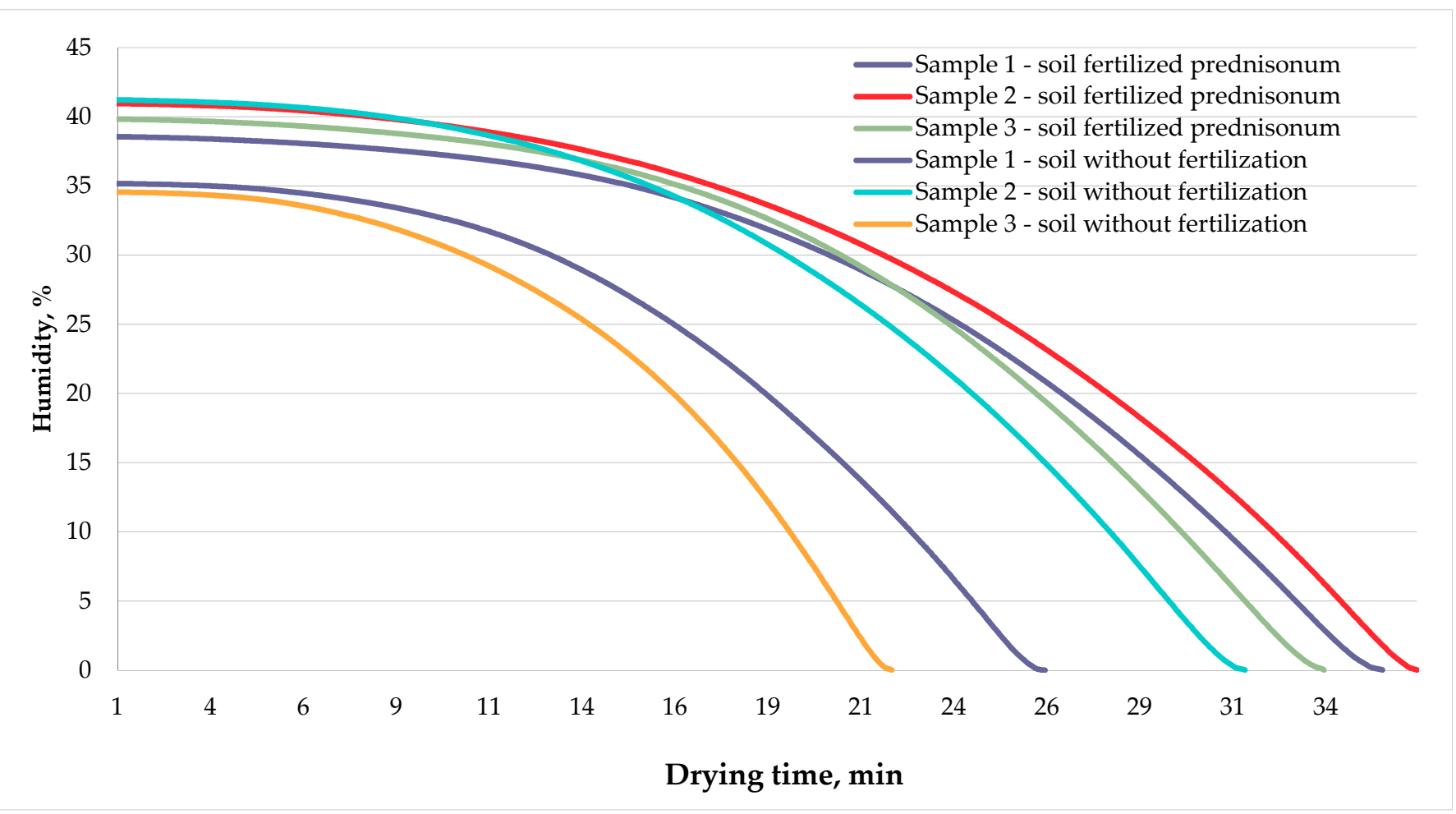

Figure 7. Soil drying curve under which the energy willow was grown.

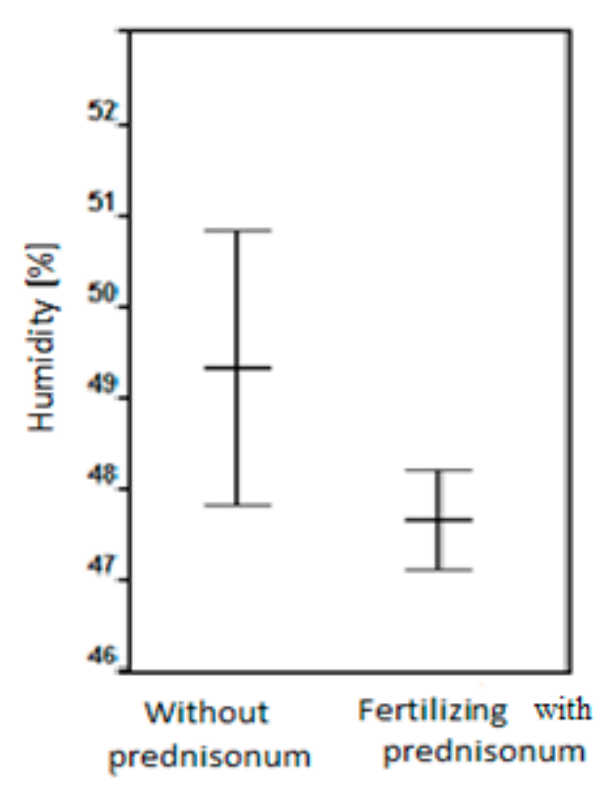

(a)

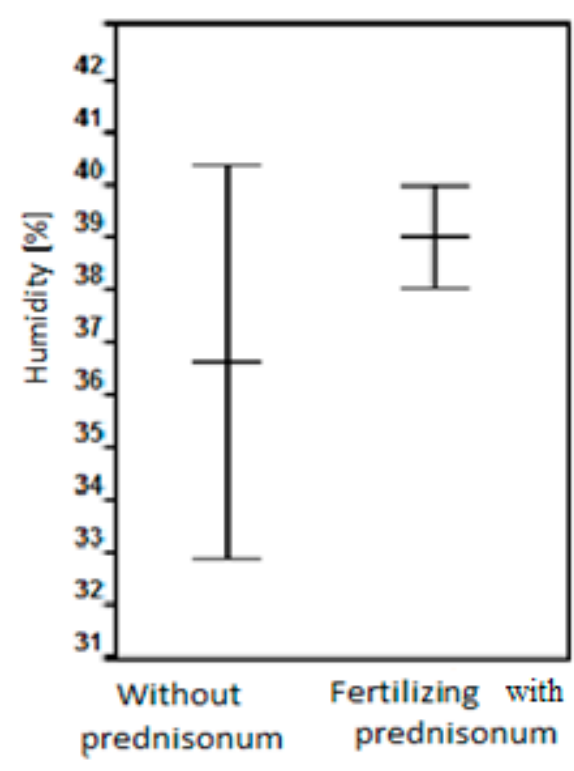

(b)

Figure 8. Significance of the effect of prednisonum fertilization on the parameters; (a) energetic willow moisture, (b) soil moisture. 


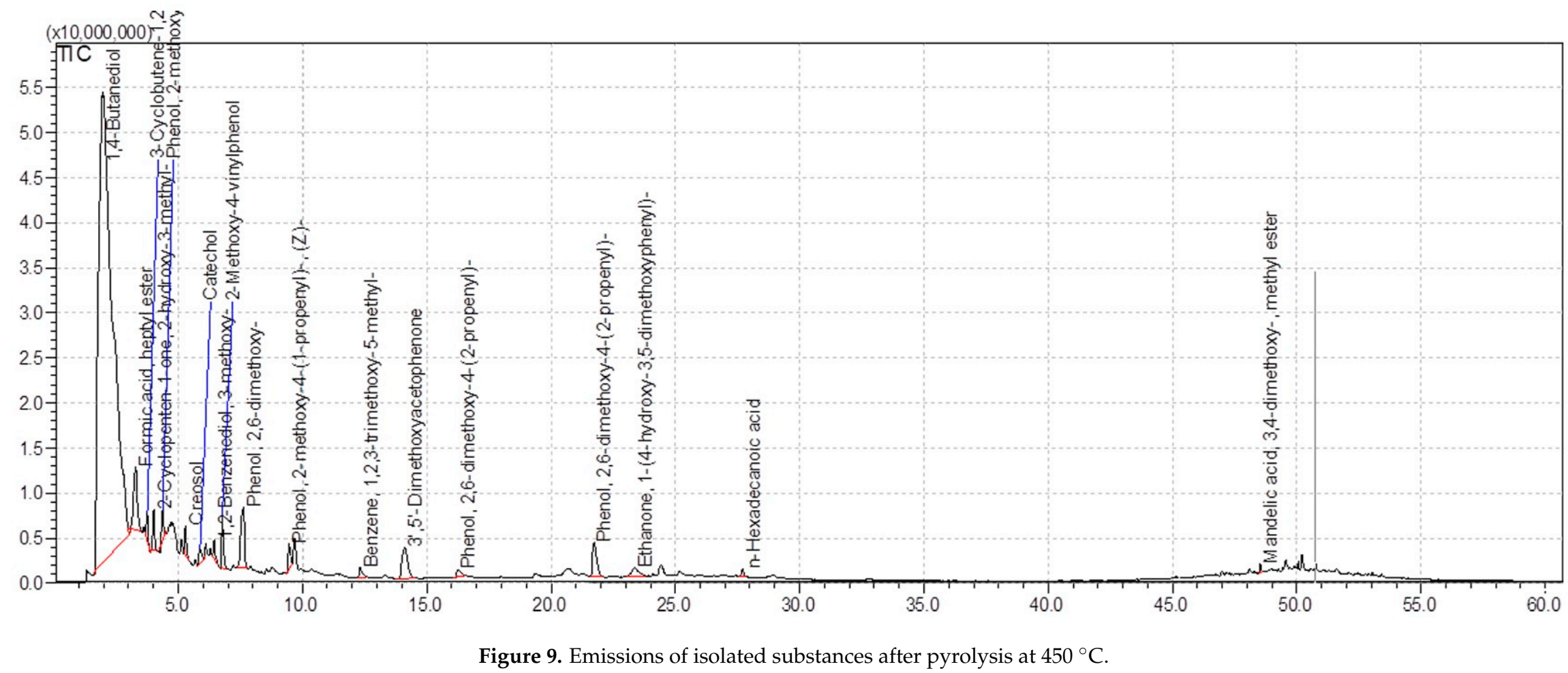


Table 5. Juxtaposition of emissions of isolated substances, $450{ }^{\circ} \mathrm{C}$.

\begin{tabular}{|c|c|c|c|c|c|}
\hline Compound Name & Retention Time & Area & Area $[\%]$ & High & High [\%] \\
\hline 1,4-Butanediol & 1.958 & $2,003,090,819$ & 82.89 & $52,198,610$ & 50.00 \\
\hline Formic acid, heptyl ester & 3.283 & $71,098,253$ & 2.94 & $6,970,557$ & 6.68 \\
\hline 3-Cyclobutene-1,2-dione, 3,4-dihydroxy- & 3.755 & $13,605,661$ & 0.56 & $3,102,704$ & 2.97 \\
\hline 2-Cyclopenten-1-one, 2-hydroxy-3-methyl- & 4.023 & $22,963,287$ & 0.95 & $4,503,736$ & 4.32 \\
\hline Phenol, 2-methoxy- & 4.377 & $16,190,938$ & 0.67 & $3,266,119$ & 3.13 \\
\hline Creosol & 5.291 & $12,450,215$ & 0.52 & $3,245,031$ & 3.11 \\
\hline Catechol & 5.874 & $13,512,952$ & 0.56 & $1,689,304$ & 1.62 \\
\hline 1,2-Benzenediol, 3-methoxy- & 6.447 & $10,402,668$ & 0.43 & $2,157,104$ & 2.07 \\
\hline 2-Methoxy-4-vinylphenol & 6.772 & $26,324,266$ & 1.09 & $5,965,092$ & 5.72 \\
\hline Phenol, 2,6-dimethoxy- & 7.628 & $68,064,193$ & 2.82 & $6,733,786$ & 6.45 \\
\hline Phenol, 2-methoxy-4-(1-propenyl)-, (Z)- & 9.462 & $16,311,773$ & 0.67 & $2,812,663$ & 2.70 \\
\hline Benzene, 1,2,3-trimethoxy-5-methyl- & 12.315 & $8,690,782$ & 0.36 & $1,061,188$ & 1.02 \\
\hline 3',5'-Dimethoxyacetophenone & 14.107 & $53,492,164$ & 2.21 & $3,414,669$ & 3.27 \\
\hline Phenol, 2,6-dimethoxy-4-(2-propenyl)- & 16.251 & $8,638,095$ & 0.36 & 789,524 & 0.76 \\
\hline Phenol, 2,6-dimethoxy-4-(2-propenyl)- & 21.722 & $44,577,278$ & 1.84 & $3,758,415$ & 3.60 \\
\hline $\begin{array}{l}\text { Ethanone, } \\
\text { 1-(4-hydroxy-3,5-dimethoxyphenyl)- }\end{array}$ & 23.363 & $18,912,065$ & 0.78 & 958,751 & 0.92 \\
\hline n-Hexadecanoic acid & 27.708 & $4,975,604$ & 0.21 & 803,894 & 0.77 \\
\hline Mandelic acid, 3,4-dimethoxy-, methyl ester & 48.529 & $3,272,281$ & 0.14 & 929,091 & 0.89 \\
\hline
\end{tabular}

The results of the thermal decomposition of energy willow indicated the thermal decomposition of structural wood-building substances (cellulose, hemicelluloses, lignin extractives, and by-products) into their volatile derivatives. The analysis showed the formation of compounds from the breakdown of polysaccharides such as cellulose to compounds, e.g., 1,4-Butanediol, formic acid, heptyl ester, and n-Hexadecanoic acid. Compounds resulting from the thermal decomposition of lignin included phenols such as Phenol, 2-methoxy, Creosol, 1,2-Benzenediol, and 3-methoxy-, [33-36].

The results obtained are in agreement with literature data related to the study of pyrolysis of wood including energy willow [35-38]. The characteristics of lignin (an amorphous condensation material resulting from the polymerisation of phenolic compounds responsible for the compressive strength of wood) have led to the development of a whole range of phenolic alcohols, in contrast to the cellulose derivatives and other polysaccharides (hemicelluloses), which are more uniform in structure than lignin [38].

After careful analysis of the raw material according to the methodology, it was noticed that during the pyrolysis, compounds were separated that were characterized against the available database [39]. One of the main compounds that separated during the early reaction was 1,4-Butanediol, with the formula $\mathrm{C}_{4} \mathrm{H}_{10} \mathrm{O}_{2}$. This organic compound, a member of the glycol group, is a colorless sticky liquid. This compound occupied the largest percentage of the surface $(82.89 \%)$ in comparison with the other chemical compounds [40].

Formic acid (formic acid, heptyl ester $\mathrm{C}_{8} \mathrm{H}_{16} \mathrm{O}_{2}$ ) and some phenols were also present. Formic acid, similarly to 1,4-Butanediol, was also released at the initial stage of pyrolysis of the raw material [41].

Production costs and biomass yields are two important elements that determine the profitability of a project related to the production of biomass from energy willow. Apart from these factors, Buholz and Volk [42] also clearly emphasized the role of the biomass price, which influences the level of production costs. In turn, Wang et al. [43] emphasized that the economic feasibility of multiple biomass feedstocks for bioenergy products is essential for the scaling up of various technologies. According to Kwaśniewski [44], the obtained, very diverse biomass production profitability indexes confirm the suggestion of many authors that the economic profitability of biomass production from energy willow is largely dependent on macroeconomic conditions. On the basis of the conducted analysis, it was found that biomass from the three-year-old energy willow can be profitably produced by well-organized units (farms, companies), which will obtain high biomass yields at relatively low production costs. This means that economies of scale are important. On the other hand, Stolarski et al. [45] analyzed the energy efficiency of the cultivation and 
production of willow chips, presented on the basis of the average, maximum, and minimum yield of fresh biomass obtained in the tested harvest cycles. Buholz and Volk [42] concluded that growing willow for biomass in New York State is unprofitable, and one of the main barriers to starting willow biomass cultivation is large capital investment. This is especially true for small-scale growers. However, various loan programs can improve profitability, especially for large growers. Langholz et al. [46] pointed out that willow has a relative agronomic advantage over other energy crops in some regions of the US.

Heller et al. [42] and Piskier [47] listed among the factors influencing the value of the energy efficiency index: the method of preparation and the type of soil site, the amount of mineral fertilization, the consumption of plant protection products, agrotechnical procedures, and especially the method of harvesting willow. The management of fallow land contributes to the activation and development of rural areas and also contributes to maintaining the land in a good agricultural condition. Therefore, in subsequent studies, it is also worth considering the economic aspects of energy willow cultivation in Poland. Although research in this area also concerns other regions of Europe and the world [48-53], the issues of economics and biomass profitability need to be continued, taking into account the changing conditions of management and the specificity of individual regions.

\section{Conclusions}

In the light of statistical analyses, it was found that there were no significant differences between biomass from energy willow, cultivated naturally and not fertilized with active substances. The soil moisture content did not differ between the analyzed crops. The average time of drying the energetic willow with a soil moisture content of $49 \%$ was about $100 \mathrm{~min}$, and that of the soil with a moisture content of about $38 \%$ was about $28 \mathrm{~min}$. The statistical analyses showed no significant differences for analysis of the feedstock and cultivation location. According to the research, it was decided that the chemical analyses of the raw material using the PY/GC-MS method will be a great opportunity to characterize the purity of raw material for energetic purposes. The PY/GC-MS examination allowed us to characterize the substances formed, which accompanied the combustion of the raw material. That is why the study of energy willow was conducted at $450{ }^{\circ} \mathrm{C}$. The analysis showed the formation of compounds from the breakdown of polysaccharides such as cellulose and compounds from the thermal decomposition of lignin included in phenols.

On the basis of the conducted research, several conclusions and generalizations were presented. Vase tests were carried out using water from each individual plant. Application of a twenty gram dose of prednisonum, which was dissolved in $400 \mathrm{~mL}$ of water, turned out to be not very significant during the cultivation of energetic willow. The result could be an insufficient dose of prednisonum or insufficient activity of active substances. Due to the statistically confirmed lack of influence of prednisonum on potential plant growth, a chemical analysis of the released compounds was performed. Further research development requires research in relation to hydration and the effects of prednisonum. Other similar substances affecting water absorption would be required to be tested and collaborated using cultivated plants. It is also a good idea to investigate how prednisonum affects other fast-growing plants used for energy production with fast photosynthesis, such as poplar.

The second part of the article focused on the chemical approach to the material under study. Practical analysis of energy willow wood indicated a more complex lignin structure in relation to the wood-building polysaccharides. It was noticed that as a result of the pyrolytic decomposition of wood biomass, compounds with a benzene ring in their structure are formed from lignin. Linear compounds arise from the breakdown of polysaccharides. The time of isolating the substance is presented in the graphs and tables in the article.

PY/GC-MS analysis of gases generated during gasification of woody biomass from willow vase tests (Salix viminalis L.) has shown the formation of organic chemical compounds that can be used in the chemical industry as a contribution to so-called green chemistry. One of these compounds is 1,4-Butanediol, which can be used as a solvent for 
plastics and paints and is also a valuable raw material for chemical synthesis (e.g., it can be used for the synthesis of tetrahydrofuran (THF)). Utilising some of the gases produced during biomass pyrolysis can significantly increase the profitability of the biomass energy process and allow for the development of green chemistry for use in global industry.

Author Contributions: Conceptualization, K.R., D.S., M.R., J.S., E.G.; Methodology, J.S., K.R., D.S., M.R.; Software, K.R., D.S., M.R., J.S.; Validation, K.R., D.S., M.R., J.S.; Formal Analysis, K.R., D.S., M.R., J.S.; Investigation, K.R., D.S., M.R., J.S.; Data Curation, K.R., D.S., M.R., J.S.; Writing-Original Draft Preparation, K.R., D.S., M.R., J.S., E.G.; Writing-Review \& Editing, K.R., D.S., M.R., J.S., E.G.; visualization, K.R., D.S., M.R., J.S., E.G.; supervision, K.R., D.S., M.R., J.S., E.G.; project administration, K.R., D.S., M.R., J.S., E.G.; funding acquisition, M.R., E.G. All authors have read and agreed to the published version of the manuscript.

Funding: The authors thank Warsaw University of Life Sciences-SGGW (Institute of Wood Sciences and Furniture) for financial support.

Institutional Review Board Statement: Not applicable.

Informed Consent Statement: Not applicable.

Data Availability Statement: Not applicable.

Conflicts of Interest: The authors declare no conflict of interest.

\section{References}

1. Saidur, R.; Islam, M.; Rahim, N.; Solangi, K. A review on global wind energy policy. Renew. Sustain. Energy Rev. 2010, 14, 1744-1762. [CrossRef]

2. Szadkowski, J. The yield of model hydrolysis and fermentation in the technology of bioethanol production from poplar wood (Populus sp.) Wydajność procesów hydrolizy i fermentacji w technologii wytwarzania bioetanolu z drewna topoli (Populus sp.). Przemyst Chem. 2017, 1, 48-50. [CrossRef]

3. Zhuang, X.; Jiang, K.; Zhao, X. Analysis of the Carbon Footprint and Its Environmental Impact Factors for Living and Travel in Shijiazhuang City. Adv. Clim. Chang. Res. 2011, 2, 159-165. [CrossRef]

4. Lewandowska, A. Study on products of enzymatic hydrolysis of pulp from poplar wood (Populus alba L.) Badanie produktów hydrolizy enzymatycznej masy celulozowej pozyskanej z drewna topoli (Populus alba L.). Przemyst Chem. 2015, 1, 104-107. [CrossRef]

5. Kells, B.J.; Swinton, S.M. Profitability of Cellulosic Biomass Production in the Northern Great Lakes Region. Agron. J. 2014, 106, 397-406. [CrossRef]

6. Metzger, J.O.; Hüttermann, A. Sustainable global energy supply based on lignocellulosic biomass from afforestation of degraded areas. Naturwissenschaften 2008, 96, 279-288. [CrossRef]

7. Shields, M.A.; Woolf, D.K.; Grist, E.P.; Kerr, S.A.; Jackson, A.; Harris, R.E.; Bell, M.C.; Beharie, R.; Want, A.; Osalusi, E.; et al. Marine renewable energy: The ecological implications of altering the hydrodynamics of the marine environment. Ocean Coast. Manag. 2011, 54, 2-9. [CrossRef]

8. Energy from renewable sources in 2013, Statistics Poland, Warsaw, 2014.

9. Energy from renewable sources in 2016, Statistics Poland, Warsaw, 2017.

10. Energy from renewable sources in 2019, Statistics Poland, Warsaw, 2020.

11. Bonassa, G.; Schneider, L.; Canever, V.B.; Cremonez, P.A.; Frigo, E.P.; Dieter, J.; Teleken, J.G. Scenarios and prospects of solid biofuel use in Brazil. Renew. Sustain. Energy Rev. 2018, 82, 2365-2378. [CrossRef]

12. Keoleian, G.A.; Volk, T.A. Renewable Energy from Willow Biomass Crops: Life Cycle Energy, Environmental and Economic Performance. Crit. Rev. Plant Sci. 2005, 24, 385-406. [CrossRef]

13. Janicka, M.; Kutkowska, A.; Paderewski, J. Diversity of vascular flora accompanying Salix viminalis L. crops depending on soil conditions. Glob. Ecol. Conserv. 2020, 23, e01068. [CrossRef]

14. Available online: http://www.woodheatassociation.org.uk/willow-the-fast-track-to-self-supply-woodfuel/ (accessed on 12 February 2021).

15. Rose, J.Q.; Yurchak, A.M.; Jusko, W.J. Dose dependent pharmacokinetics of prednisone and prednisolone in man. J. Pharmacokinet. Biopharm. 1981, 9, 389-417. [CrossRef]

16. Roberts, R.J.; Welch, S.M.; Devlin, J.W. Corticosteroids for Prevention of Postextubation Laryngeal Edema in Adults. Ann. Pharmacother. 2008, 42, 686-691. [CrossRef]

17. Pacaldo, R.S.; Volk, T.A.; Briggs, R.D. Greenhouse Gas Potentials of Shrub Willow Biomass Crops Based on Below- and Aboveground Biomass Inventory along a 19-Year Chronosequence. BioEnergy Res. 2013, 6, 252-262. [CrossRef] 
18. Kamil, K.R.; Anita, K.; Roman, K.K.; Konieczna, A. Evaluation of a different fertilisation in technology of corn for silage, sugar beet and meadow grasses production and their impact on the environment in Poland. Afr. J. Agric. Res. 2015, 10, 1351-1358. [CrossRef]

19. Rowe, R.L.; Street, N.; Taylor, G. Identifying potential environmental impacts of large-scale deployment of dedicated bioenergy crops in the UK. Renew. Sustain. Energy Rev. 2009, 13, 271-290. [CrossRef]

20. Ericsson, K.; Rosenqvist, H.; Ganko, E.; Pisarek, M.; Nilsson, L. An agro-economic analysis of willow cultivation in Poland. Biomass Bioenergy 2006, 30, 16-27. [CrossRef]

21. Weger, J.; Bubeník, J. Biomass production of new willow and poplar clones grown on agricultural soil in a three year rotation after six years. Acta Pruhoniciana 2012, 100, 51-62.

22. Moritz, K.K.; Björkman, C.; Parachnowitsch, A.L.; Stenberg, J.A. Female Salix viminalis are more severely infected by Melampsora spp. but neither sex experiences associational effects. Ecol. Evol. 2016, 6, 1154-1162. [CrossRef] [PubMed]

23. Juliszewski, T.; Kwaśniewski, D.; Pietrzykowski, M.; Tylek, P.; Walczyk, J.; Woś, B.; Likus, J. Root biomass distribution in an energy willow plantation. Agric. Eng. 2015, 4, 43-49. [CrossRef]

24. Spinelli, R.; Nati, C.; Magagnotti, N. Harvesting short-rotation poplar plantations for biomass production. Croat. J. For. Eng. 2008, 29, 129-139.

25. Adegbidi, H.G.; Volk, T.A.; White, E.H.; Briggs, R.D.; Abrahamson, L.P.; Bickelhaupt, D.H. Biomass and nutrient export by willow clones in experimental bioenergy plantations in New York State. Biomass Bioenergy 2001, 20, 399-411. [CrossRef]

26. Ilek, A.; Kucza, J.; Morkisz, K. Hygroscopicity of the bark of selected forest tree species. iFor. Biogeosci. For. 2017, 10, 220-226. [CrossRef]

27. McKendry, P. Energy production from biomass (part 1): Overview of biomass. Bioresour. Technol. 2002, 83, 37-46. [CrossRef]

28. Labrecque, M.; Teodorescu, T.I. High biomass yield achieved by Salix clones in SRIC following two 3-year coppice rotations on abandoned farmland in southern Quebec, Canada. Biomass Bioenergy 2003, 25, 135-146. [CrossRef]

29. Nurek, T.; Roman, K. Effect of mineral matter content on specific density of forest biomass. Ann. Wars. Univ. Life Sci. SGGW Agric. 2014, 64, 109-116.

30. Volk, T.; Abrahamson, L.; Nowak, C.; Smart, L.; Tharakan, P.; White, E. The development of short-rotation willow in the northeastern United States for bioenergy and bioproducts, agroforestry and phytoremediation. Biomass Bioenergy 2006, 30, 715-727. [CrossRef]

31. Martin, P.J.; Stephens, W. Willow growth in response to nutrients and moisture on a clay landfill cap soil. I. Growth and biomass production. Bioresour. Technol. 2006, 97, 437-448. [CrossRef]

32. Muller, M.; Horníčková, Š; Hrabě, P.; Mařík, J. Analysis of physical, mechanical and chemical properties of seeds and kernels of Jatropha curcas. Res. Agric. Eng. 2016, 61, 99-105. [CrossRef]

33. Devore, J.; Farnum, N. Applied Statistics for Engineers and Scientists; Duxbury Press: London, UK, $1999 ;$ pp. 23-24.

34. Berthouex, P.M.; Brown, L.C. Statistics for Environmental Engineers; Lewis Publishers: Boca Raton, FL, USA, $1994 ;$ pp. 16-17.

35. Fahmi, R.; Bridgwater, A.; Darvell, L.; Jones, J.; Yates, N.; Thain, S.; Donnison, I. The effect of alkali metals on combustion and pyrolysis of Lolium and Festuca grasses, switchgrass and willow. Fuel 2007, 86, 1560-1569. [CrossRef]

36. Nowakowski, D.; Jones, J.; Brydson, R.; Ross, A. Potassium catalysis in the pyrolysis behaviour of short rotation willow coppice. Fuel 2007, 86, 2389-2402. [CrossRef]

37. Greenhalf, C.; Nowakowski, D.; Harms, A.; Titiloye, J.; Bridgwater, A. Sequential pyrolysis of willow SRC at low and high heating rates-Implications for selective pyrolysis. Fuel 2012, 93, 692-702. [CrossRef]

38. Xin, X.; Pang, S.; Mercader, F.D.M.; Torr, K.M. The effect of biomass pretreatment on catalytic pyrolysis products of pine wood by Py-GC/MS and principal component analysis. J. Anal. Appl. Pyrolysis 2019, 138, 145-153. [CrossRef]

39. Janiszewska, D. Potencjał energetyczny upraw wierzby na gruntach marginalnych w Polsce. Zesz. Nauk. Wydziału Nauk Ekon. Politech. Koszalińskiej 2014, 18, 47-56.

40. Grzybek, A.; Świętochowski, A.; Hryniewicz, M.; Roman, K. Analiza możliwości wieloletniego pozyskania biomasy dla bloku biomasowego $50 \mathrm{MW}$ w Elektrowni Jaworzno II-EL" Polbiom Own study as part of an internal project, Warszawa. 2011, pp. 65-73.

41. Pasyniuk, P. Prawne, technologiczne, środowiskowe i ekonomiczne uwarunkowania rozwoju produkcji odnawialnych źródeł energii w Polsce opartych na biomasie pochodzenia rolniczego. Masz. IBMER Warszawa 2008, 33.

42. Buchholz, T.; Volk, T. Profitability of Willow Biomass Crops Affected by Incentive Programs. BioEnergy Res. 2012, 6, 53-64. [CrossRef]

43. Wang, Y.; Wang, J.; Zhang, X.; Grushecky, S. Environmental and Economic Assessments and Uncertainties of Multiple Lignocellulosic Biomass Utilization for Bioenergy Products: Case Studies. Energies 2020, 13, 6277. [CrossRef]

44. Kwaśniewski, D. Koszty i opłacalność produkcji biomasy z trzyletniej wierzby energetycznej. Inżynieria Rol. $2011,1,145-154$.

45. Stolarski, M.J.; Krzyżaniak, M.; Szczukowski, S.; Tworkowski, J. Efektywność energetyczna produkcji biomasy wierzby w jednorocznym i trzyletnim cyklu zbioru. Fragm. Agron. 2014, 31, 88-95.

46. Langholtz, M.; Eaton, L.; Davis, M.; Shedden, M.; Brandt, C.; Volk, T.; Richard, T. Economic comparative advantage of willow biomass in the Northeast USA. Biofuels Bioprod. Biorefining 2018, 13, 74-85. [CrossRef]

47. Heller, M.C.; Keoleian, G.A.; Volk, T.A. Life cycle assessment of a willow bioenergy cropping system. Biomass Bioenergy 2003, 25, 147-165. [CrossRef] 
48. Piskier, T. Efektywność energetyczna uprawy wierzby w różnych warunkach glebowych. Inżynieria Rol. 2008, 12, 215-220.

49. Konieczna, A.; Roman, K.; Roman, M.; Śliwiński, D.; Roman, M. Energy Efficiency of Maize Production Technology: Evidence from Polish Farms. Energies 2020, 14, 170. [CrossRef]

50. Gajewski, R. Rynek biomasy w Polsce-Stan obecny i perspektywy rozwoju, Materiały konferencyjne Polska Izba Biomasy. 2014, p. 8 .

51. Stolarski, M.J.; Rosenqvist, H.; Krzyżaniak, M.; Szczukowski, S.; Tworkowski, J.; Gołaszewski, J.; Olba-Zięty, E. Economic comparison of growing different willow cultivars. Biomass Bioenergy 2015, 81, 210-215. [CrossRef]

52. Rosenqvist, H.; Dawson, M. Economics of willow growing in Northern Ireland. Biomass Bioenergy 2005, 28, 7-14. [CrossRef]

53. Liu, W.; Wang, J.; Richard, T.L.; Hartley, D.S.; Spatari, S.; Volk, T.A. Economic and life cycle assessments of biomass utilization for bioenergy products. Biofuels Bioprod. Biorefin. 2017, 11, 633-647. [CrossRef] 